\title{
Evaluation of Characteristics and Clinical Outcomes of Vaginismus Treatment During Pregnancy
}

\author{
(1) Süleyman Eserdağ, ${ }^{1}$ [D Emine Eda Akalın²
}

'Department of Obstetrics and Gynecology, Altınbaş University Faculty of Medicine, İstanbul, Turkey ${ }^{2}$ Department of Gynecology and Obstetrics, Kartal Dr. Lütfi Kırdar City Hospital, İstanbul, Turkey

Submitted: 15.11 .2020 Accepted: 17.12.2020

Correspondence: Süleyman Eserdağ, Altınbaş Üniversitesi Tıp Fakültesi, Kadın Hastalıkları ve Doğum Kliniği, İstanbul, Turkey

E-mail: suleyman@eserdag.com

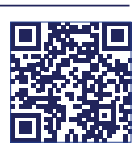

Keywords: Delivery; pregnancy; success treatment; vaginismus.

\begin{abstract}
Objective: Vaginismus is a common female psychosexual dysfunction that can cause a significant deterioration in quality of life. The aim of this study was to evaluate the characteristics of vaginismus during pregnancy and treatment outcomes.
\end{abstract}

Methods: A total of 17 pregnant women with a normal-risk pregnancy and vaginismus, and 34 vaginismus patients who were not pregnant (control group) and their partners were included in the study. All of the patients were treated with cognitive therapy and behavioral therapy. Treatment did not result in any pregnancy complications.

Results: The control group required significantly more therapy sessions and a greater total number of treatment days than the pregnant vaginismus group. Twelve of the pregnant women with vaginismus had a cesarean section, and 5 had a vaginal delivery. Seven of the cesarean deliveries were elective, and 5 were due to medical indications. After treatment, 16 couples $(94.1 \%)$ from the pregnant group reported that they had very comfortable, full penetrative sexual intercourse, while I couple said that they had achieved full penetration, but it was painful.

Conclusion: This is believed to be the first study to examine vaginismus treatment during pregnancy. The findings indicated that vaginismus patients can undergo sexual therapy during pregnancy safely, and that results may be achieved sooner than with non-pregnant vaginismus patients with valuable benefits. Treatment can reduce the preference for a caesarean section, lessen anxiety related to gynecological exams and delivery.

\section{INTRODUCTION}

Vaginismus is one of the most common forms of female psychosexual dysfunction, and can cause significant a deterioration in a woman's quality of life, since it may involve physical pain, in addition to psychological, psychosomatic, and relationship problems. ${ }^{[1,2]}$ Vaginismus is now recognized as both a physical and an emotional disorder. The definition of vaginismus was updated in the fifth edition of the Diagnostic and Statistical Manual of Mental Disorders (DSM) and the condition is now defined as a subset of genito-pelvic pain/penetration disorder. ${ }^{[3,4]}$ The new definition more thoroughly acknowledges a range of psychological foundations. It no longer relies on involuntary muscle spasms as the cause of painful or impossible vaginal penetration, though this continues to be a potential component of the condition. The presence of a vaginal muscle spasm can help distinguish vaginismus from other sexual pain disorders. Therefore, a thorough history and physical examination are required to diagnose this disorder. ${ }^{[5]}$ The prevalence of vaginismus in the general population is difficult to estimate and varies in the literature, but it has been reported to be $1 \%$ to $6 \%$ and $5 \%$ to $17 \%$ in a clinical setting. ${ }^{[6]}$

Although a wide variety of vaginismus subtypes have been described, the most frequent are primary and secondary vaginismus. In primary, or lifelong vaginismus, it has always been impossible to insert anything into the vagina. In secondary (acquired) vaginismus, penetration was once possible, but later became intolerable, often as a result of fear following a traumatic event related to the genital area. ${ }^{[4,7,8]}$ Several etiologies have been suggested for vaginismus. These include a lack of proper sexual education and understanding; somatic/psychological causes, including apprehension and the anticipation of pain at the first sexual experience, negative beliefs that may stem from religious, moral or cultural orthodoxy, anxiety disorders, or sexual abuse in childhood; as well as organic disorders, such as endometriosis, infection, hymen anomalies, and vaginal atrophy. ${ }^{[9-11]}$ Since vaginismus has a broad range of etiological factors, treatment options vary. Effective treat- 
ments for vaginismus include systematic desensitization, psychosexual therapy, sexual education, botulinum toxin injections, and pharmacotherapy. Although there are several controlled studies on treatment management of vaginismus, the available research remains insufficient. Most recommendations are based on the evidence of descriptive case-control studies, clinical experience, and expert opinion. ${ }^{[2,12,13]}$

There is not much information about the reproductive, pregnancy, and birth outcomes of women with vaginismus. These women avoid vaginal intercourse and therefore may struggle with infertility. ${ }^{[14,15]}$ Since vaginismus is still considered a taboo, affected women are typically reluctant to voice their complaints and may avoid consulting a gynecologist. This contributes to the lack of clear information, particularly about the frequency of pregnancy in patients with vaginismus. To the best of our knowledge, there are no studies regarding the administration of vaginismus treatment to pregnant patients or pregnancy results in vaginismus patients. The hypothesis of this study was that vaginismus treatment provided during pregnancy could facilitate gynecological exams, diminish anxiety about delivery, increase the possibility of vaginal birth, and prevent the postponement of treatment. This research was designed to determine the characteristics, clinical outcomes, efficacy, and safety of vaginismus treatment during pregnancy.

\section{MATERIALS AND METHODS}

This retrospective study was conducted at a gynecology clinic in Turkey with patient data collected between January I, 2015 and January I, 2019. The tenets of the Declaration of Helsinki were observed and written, informed consent was obtained from all of the participants. The study was approved by the Kartal Dr. Lütfi Kırdar City Hospital Clinical Research Ethics Committee on March 30, 2020 (no: 2020/5 I4//86/2).

In all, 17 pregnant women with vaginismus with a normal-risk pregnancy and 34 randomized vaginismus patients who were not pregnant (controls) were included. The criterion for admission to the vaginismus+pregnancy patient group was a normal-risk pregnancy in the second trimester (13-28 weeks). Exclusion criteria included a history of vaginal bleeding during pregnancy, any risk of amniotic membrane rupture or preterm delivery, pelvic pain, growth retardation, abruptio placentae, or placenta previa. Both the test and ultrasound results of previous prenatal visits were examined in the first session, and the patients were re-examined and reevaluated based on additional ultrasound images. Patients who were diagnosed with provoked vulvar vestibulitis in a gynecological examination were also excluded.

After recording a comprehensive patient history, including demographic, medical, and psychosexual questions, a simple gynecological exam was performed in the lithotomy position to evaluate the presence of any congenital genital abnormalities, and perform a gentle digital touch to the vaginal introitus to determine the degree of vaginismus. The absolute diagnosis of vaginismus was made based on the evaluation of the anamnesis and pelvic examination. The patients were categorized according to the Lamont classification system: Grade I: Patient is able to relax for pelvic examination; Grade 2: Patient is unable to relax for pelvic examination; Grade 3: Buttocks lift off table, early retreat; Grade 4: Generalized retreat, buttocks lift up, thighs close, patient retreats.

The detailed history and gynecological exam findings of all of the study patients were examined and appropriate treatment protocols were designed for each patient. All of the members of the study were treated with cognitive behavioral therapy (CBT) sessions with her partner. The couples were given very detailed information about anatomy and physiology, including the hymen and genital organs, and sexuality, particularly facts about the first sexual experience. A careful and thoughtful effort was made to eliminate incorrect, incomplete, or exaggerated information about sexuality. Behavioral therapy sessions were provided in a clinical setting by therapists trained and experienced in sexual therapy. The therapy focused on reducing anxiety through systematic desensitization by providing the patients with exercises to be performed every day for 60-90 minutes. The treatment included pelvic muscle rehabilitation exercises, Kegel exercises, mirror exercises, sensate focus exercises, and gradually increasing touching and dilator exercises. The patients were asked to repeat these exercises at home individually and then as a couple. Lubricating cream was used in dilator exercises, and the device was not advanced as far as the cervix. In addition, hypnotherapy was performed with patients who displayed excessive anxiety and low self-confidence in order to provide relief and increase motivation. Simple surgical interventions such as a hymenotomy and hymenectomy were performed for patients with congenital anatomical abnormalities, such as a crescent hymen or a septate hymen. CBT techniques were used in follow-up. The treatment team included gynecologists, psychologists, family counselors, physiotherapists, and nurses who are trained in this field work. No pregnancy complications were encountered during treatment. The demographic characteristics of both groups, vaginismus level (according to the Lamont classification) when they began treatment, types of treatment sessions, days in treatment, treatment results, and pregnancy results were analyzed.

\section{Statistical Analysis}

The data were evaluated using the IBM SPSS Statistics for Windows, Version 25 software (IBM Corp., Armonk, New York, USA). Descriptive statistics were provided as number $(n)$, percent $(\%)$, mean $\pm S D$, median $(M)$, first quarter (QI) and third quarter (Q3). The normal distribution of data of numerical variables was evaluated using the Shapiro-Wilk normality test and $\mathrm{Q}-\mathrm{Q}$ graphs. The homogeneity of the variances was evaluated with the Levene test. 
Comparisons between groups were made using the independent samples t-test for variables with normal distribution and the Mann-Whitney $U$ test for variables that did not demonstrate normal distribution. Fisher's exact test was used in $2 \times 2$ and $\mathrm{R} \times \mathrm{C}$ tables to compare categorical variables. ${ }^{[17]} \mathrm{A}$ level of $\mathrm{p}<0.05$ was considered statistically significant.

\section{RESULTS}

In the pregnant vaginismus group, $47.1 \%$ of the patients were university graduates, with an average age of $25.7 \pm 1.9$ years. The Lamont classification of vaginismus indicated that $58.8 \%$ were grade 2 and $64.7 \%$ had had partial sexual intercourse. Table I provides details of the demographic

Table I. Demographic characteristics

\begin{tabular}{|c|c|c|c|c|c|c|}
\hline \multirow[t]{3}{*}{ Variable } & \multicolumn{4}{|c|}{ Groups } & \multicolumn{2}{|c|}{ Test statistics } \\
\hline & \multicolumn{2}{|c|}{ Pregnant vaginismus } & \multicolumn{2}{|c|}{ Control (non-pregnant) } & \multirow[b]{2}{*}{$\chi^{2}$} & \multirow[b]{2}{*}{$\mathbf{p}$} \\
\hline & $\mathbf{n}$ & $\%$ & $\mathbf{n}$ & $\%$ & & \\
\hline \multicolumn{7}{|l|}{ Education level } \\
\hline Primary school & 4 & 23.5 & 2 & 5.9 & 6.653 & 0.257 \\
\hline Middle school & I & 5.8 & 7 & 20.6 & & \\
\hline High school & 2 & 11.8 & 7 & 20.6 & & \\
\hline Associate's degree & 2 & 11.8 & 2 & 5.9 & & \\
\hline License & 8 & 47.1 & 14 & 41.1 & & \\
\hline Master's degree & 0 & 0.0 & 2 & 5.9 & & \\
\hline \multicolumn{7}{|l|}{ Employment } \\
\hline Housewife & 7 & 41.2 & 19 & 55.9 & 5.172 & 0.160 \\
\hline Laborer & 0 & 0.0 & 2 & 5.9 & & \\
\hline Civil servant & 9 & 52.9 & 8 & 23.5 & & \\
\hline Private sector & 1 & 5.9 & 5 & 14.7 & & \\
\hline \multicolumn{7}{|l|}{ Consanguineous marriage } \\
\hline Yes & 3 & 17.6 & 3 & 8.9 & 0.850 & 0.650 \\
\hline No & 14 & 82.4 & 31 & 91.1 & & \\
\hline \multicolumn{7}{|l|}{ Marriage type } \\
\hline Love & 12 & 70.6 & 25 & 73.5 & 0.049 & 1.000 \\
\hline Arranged marriage & 5 & 29.4 & 9 & 26.5 & & \\
\hline \multicolumn{7}{|l|}{ Family structure } \\
\hline Religious & 9 & 52.9 & 17 & 50.0 & 0.444 & 0.836 \\
\hline Traditional & 7 & 41.2 & 13 & 38.2 & & \\
\hline Modern & I & 5.9 & 4 & 11.8 & & \\
\hline \multicolumn{7}{|c|}{ History of vaginismus in relatives } \\
\hline Yes & 6 & $35.3^{\mathrm{a}}$ & 2 & $5.9^{\mathrm{b}}$ & 7.413 & 0.012 \\
\hline No & II & 64.7 & 32 & 94.1 & & \\
\hline \multicolumn{7}{|l|}{ Lamont Grade } \\
\hline Grade I & 5 & 29.4 & 6 & 17.6 & 3.535 & 0.339 \\
\hline Grade 2 & 10 & 58.8 & 16 & 47.1 & & \\
\hline Grade 3 & 2 & 11.8 & 10 & 29.4 & & \\
\hline Grade 4 & 0 & 0.0 & 2 & 5.9 & & \\
\hline \multicolumn{7}{|c|}{ Sexual intercourse history } \\
\hline Never & 6 & $35.3^{\mathrm{a}}$ & 28 & $82.3^{\mathrm{b}}$ & 15.565 & $<0.001$ \\
\hline Partial & II & $64.7^{\mathrm{a}}$ & 4 & $11.8^{b}$ & & \\
\hline Once & 0 & $0.0^{\mathrm{a}}$ & 2 & $5.9^{\mathrm{a}}$ & & \\
\hline \multicolumn{7}{|l|}{ Previous treatment } \\
\hline Yes & 7 & 41.3 & 17 & 50.0 & 0.354 & 0.767 \\
\hline No & 10 & 58.7 & 17 & 50.0 & & \\
\hline \multicolumn{7}{|l|}{ Sexual desire } \\
\hline Normal & II & 64.7 & 25 & 73.5 & 0.670 & 0.785 \\
\hline Decreased & 4 & 23.5 & 7 & 20.6 & & \\
\hline None & 2 & 11.8 & 2 & 5.9 & & \\
\hline
\end{tabular}


Table I. Demographic characteristics (continue)

\begin{tabular}{|c|c|c|c|c|c|c|}
\hline \multirow[t]{3}{*}{ Variable } & \multicolumn{4}{|c|}{ Groups } & \multicolumn{2}{|c|}{ Test statistics } \\
\hline & \multicolumn{2}{|c|}{ Pregnant vaginismus } & \multicolumn{2}{|c|}{ Control (non-pregnant) } & \multirow[b]{2}{*}{$\chi^{2}$} & \multirow[b]{2}{*}{$\mathbf{p}$} \\
\hline & $\mathbf{n}$ & $\%$ & $\mathbf{n}$ & $\%$ & & \\
\hline \multicolumn{7}{|l|}{ Vaginal wetness } \\
\hline Normal & 14 & 82.4 & 28 & 82.4 & 0.000 & 1.000 \\
\hline Decreased & 3 & 17.6 & 6 & 17.6 & & \\
\hline \multicolumn{7}{|l|}{ Clitoral orgasm } \\
\hline Decreased & 3 & 17.6 & 0 & 0.0 & 6.462 & 0.058 \\
\hline Yes & II & 64.8 & 28 & 82.4 & & \\
\hline No & 3 & 17.6 & 6 & 17.6 & & \\
\hline \multicolumn{7}{|l|}{ Frequency of sexual intercourse } \\
\hline Decreased & 6 & 35.3 & 13 & 38.2 & 1.308 & 0.496 \\
\hline No attempt & 7 & 41.2 & 9 & 26.5 & & \\
\hline Normal & 4 & 23.5 & 12 & 35.3 & & \\
\hline \multicolumn{7}{|l|}{ First source of sexual information source } \\
\hline Friend & 10 & 58.8 & 24 & 70.6 & 0.706 & 0.531 \\
\hline Other & 7 & 41.2 & 10 & 29.4 & & \\
\hline \multicolumn{7}{|l|}{ Trauma } \\
\hline Enuresis after 5 years of age & I & 5.9 & 4 & 11.8 & 0.554 & 0.826 \\
\hline Sexual abuse & 5 & 29.4 & 8 & 23.5 & & \\
\hline None & 11 & 64.7 & 22 & 64.7 & & \\
\hline \multicolumn{7}{|l|}{ History of difficulty with gynecological exam } \\
\hline Yes & 3 & 17.6 & 3 & 8.8 & 0.850 & 0.650 \\
\hline No & 14 & 82.4 & 31 & 91.2 & & \\
\hline \multicolumn{7}{|l|}{ Sexual desire of the partner } \\
\hline Decreased & 4 & 23.5 & 5 & 14.7 & 0.607 & 0.699 \\
\hline Normal & 13 & 76.5 & 29 & 85.3 & & \\
\hline \multicolumn{7}{|l|}{ Sexual disorder in male partner } \\
\hline Loss of sexual desire & $2^{\mathrm{a}}$ & 11.8 & $0^{\mathrm{b}}$ & 0.0 & $|4.02|$ & 0.018 \\
\hline Erectile dysfunction & $\mathrm{I}^{\mathrm{a}}$ & 5.9 & $0^{a}$ & 0.0 & & \\
\hline Premature ejaculation & $\mathrm{I}^{\mathrm{a}}$ & 5.9 & $4^{a}$ & 11.8 & & \\
\hline Primary premature ejaculation & $2^{\mathrm{a}}$ & 11.8 & $0^{\mathrm{b}}$ & 0.0 & & \\
\hline Premature ejaculation, SED & $\mathrm{I}^{\mathrm{a}}$ & 5.9 & $0^{\mathrm{a}}$ & 0.0 & & \\
\hline Secondary sexual reluctance & $\mathrm{I}^{\mathrm{a}}$ & 5.9 & $4^{a}$ & 11.8 & & \\
\hline Secondary erectile dysfunction & $0^{a}$ & 0.0 & $\mathrm{I}^{\mathrm{a}}$ & 2.9 & & \\
\hline None & $9^{a}$ & 52.8 & $25^{\mathrm{a}}$ & 73.5 & & \\
\hline \multicolumn{7}{|l|}{ Partner's personality structure } \\
\hline Insightful and patient & 13 & 76.5 & 26 & 76.5 & 0.000 & 1.000 \\
\hline Frustrated and nervous & 4 & 23.5 & 8 & 23.5 & & \\
\hline \multicolumn{7}{|l|}{ Sexual experience of the partner } \\
\hline Yes & 4 & 23.5 & 16 & 47.1 & 2.632 & 0.135 \\
\hline No & 13 & 76.5 & 18 & 52.9 & & \\
\hline \multicolumn{7}{|l|}{ Applied treatment methods } \\
\hline CBT & 16 & 94.1 & 32 & 94.2 & 3.000 & 0.713 \\
\hline $\mathrm{CBT}+$ hymenotomy & 0 & 0.0 & 1 & 2.9 & & \\
\hline CBT + hymenotomy + hypnotherapy & 0 & 0.0 & 1 & 2.9 & & \\
\hline $\mathrm{CBT}+$ hymenectomy & 1 & 5.9 & 0 & 0.0 & & \\
\hline \multicolumn{7}{|l|}{ Sexual life after treatment } \\
\hline Painful/difficult relationship & 1 & 5.9 & 3 & 8.8 & 0.668 & 1.000 \\
\hline Normal & 16 & 94.1 & 30 & 88.3 & & \\
\hline Vaginismus & 0 & 0.0 & 1 & 2.9 & & \\
\hline
\end{tabular}

Superscript $\mathrm{a}$ and $\mathrm{b}$ indicate the differences between groups in each category. CBT: Cognitive behavioral therapy; SED: Secondary erectile dysfunction. 
Table 2. Comparison of demographic characteristics

\begin{tabular}{lcccc}
\hline Variable & \multicolumn{2}{c}{ Groups } & & Test statistics \\
\cline { 2 - 4 } & Pregnant with vaginismus & $\begin{array}{c}\text { Control } \\
\text { (vaginismus, } \\
\text { not pregnant) }\end{array}$ & t/z & $\mathbf{n}$ \\
\hline Age (mean $\pm S D)$ & $25.7 \pm 1.9$ & $26.8 \pm 4.0$ & 1.309 & 0.197 \\
Partner's age (mean $\pm S D)$ & $28.1 \pm 4.2$ & $29.1 \pm 3.2$ & 0.929 & 0.357 \\
Length of marriage (months) $M\left(Q_{1}-Q_{3}\right)$ & $14.0(11.0-30.0)$ & $24.0(11.0-42.0)$ & $1.483^{*}$ & 0.138 \\
Duration of relationship prior to marriage & $36.0(19.0-82.0)$ & $48.0(33.0-84.0)$ & $1.004^{*}$ & 0.315 \\
(months) $M\left(Q_{1}-Q_{3}\right)$ & & & & \\
Total number of sessions $M\left(Q_{1}-Q_{3}\right)$ & $6.0(3.0-7.0)$ & $12.0(6.0-12.0)$ & $3.868^{*}$ & $<0.001$ \\
Total treatment days $M\left(Q_{1}-Q_{3}\right)$ & $3.0(3.0-3.5)$ & $4.0(3.0-4.0)$ & $2.070^{*}$ & 0.038 \\
\hline
\end{tabular}

"Mann-Whitney $U$ test.

Table 3. Characteristics of the pregnant vaginismus group and pregnancy outcomes

\begin{tabular}{lcc}
\hline Variables & \multicolumn{2}{c}{$\begin{array}{c}\text { Pregnant with } \\
\text { vaginismus group }\end{array}$} \\
\cline { 2 - 3 } & n & $\%$ \\
\hline Gender & & \\
Male & 8 & 47.1 \\
Female & 9 & 52.9 \\
Type of delivery & & \\
Cesarean & 12 & 70.6 \\
Vaginal & 5 & 29.4 \\
Cesarean indication & & \\
Elective & 7 & 58.5 \\
Fetal macrosomia & 1 & 8.3 \\
Repeated cesarean & 1 & 8.3 \\
Preeclampsia & I & 8.3 \\
Preterm labor & I & 8.3 \\
Primigravida breech presentation & I & 8.3 \\
Newborn complication & & \\
Premature & I & 5.9 \\
None & 16 & 94.1 \\
\hline & &
\end{tabular}

characteristics of the study patients, the family structure, the Lamont degree, prior treatment attempts, sexual desire, vaginal wetness, clitoral orgasm, attempts to perform sexual intercourse, the first source of sexual information, sexual abuse, difficult gynecological examination, sexual desire of the partner, personality of the partner, the partner's sexual experience, and treatment methods used. The results were statistically similar between the 2 groups.

In the pregnant vaginismus group, the incidence of vaginismus in the family was statistically higher than that of the control group $(p=0.012)$. The number of patients who had no sexual intercourse in the control group was statistically higher than that of the patients in the pregnant vaginismus group $(p<0.001)$. A history of partial penetration was significantly higher in the pregnant vaginismus group than in the control group. The distribution of sexual problems in the partner differed between the groups $(p=0.018)$. In the pregnant vaginismus group, a loss of sexual desire and premature ejaculation were significantly higher than in the control group. Evaluation of the sexual life of the couples after vaginismus treatment revealed that 16 couples (94.1\%) in the pregnant vaginismus group reported very comfortable sexual intercourse, while I couple said that though they had achieved full penetration, it was painful. In the control group, 30 couples (88.3\%) described very comfortable intercourse, 3 couples described painful sexual intercourse, and I couple reported continuing vaginismus.

Table 2 illustrates that the age of the patient, partner's age, length of marriage, and duration of the relationship prior to marriage were similar between the groups. However, the number of sessions that the control group participated in and the total number of days were significantly greater than those of the pregnant women with vaginismus.

The pregnancy characteristics are shown in Table 3. Twelve of the pregnant women had a cesarean delivery and 5 had a vaginal delivery. Seven of the cesarean deliveries were elective, and 5 were performed as a result of various medical indications.

\section{DISCUSSION}

Vaginismus is thought to be one of the most common female types of psychosexual dysfunction. It has been reported that $9 \%$ of women calling an Italian helpline to discuss sexual concerns sought information about vaginismus. ${ }^{[18]}$ The results of a case-control study in Mexico indicated that $9.1 \%$ of the participants had vaginismus according to the DSM-IV-TR criteria. ${ }^{[19]}$ A study conducted in Ghana note that 205 (68.1\%) of 301 women randomly selected reported vaginismus symptoms. ${ }^{[20]}$ Women with vaginismus have been said to comprise $5 \%$ to $17 \%$ of sexual dysfunction clinic patients in the UK and USA. ${ }^{[2]}$ Dogan ${ }^{[21]}$ found that vaginismus was present in 41 of 54 female patients $(75.9 \%)$ of a sex therapy clinic in Turkey. The range in the reported prevalence of vaginismus is due 
to both social differences and inconsistent definitions used in studies.

The symptoms of vaginismus vary. They include anxiety, involuntary contractions and/or pain during vaginal penetration, and the inability to tolerate a gynecological examination or insertion of any foreign object into the vagina. The symptoms are important because they help distinguish vaginismus from vulvodynia and provoked vestibulodynia. Spasm at the level of introitus is suggestive of vaginismus. [22,23] In provoked vestibulodynia, hypersensitivity of the nerve fibers results in pain upon even a light vestibular touch, such as with a cotton swab, rather than as a result of anxiety. Treatment of vaginismus has a higher success rate than other sexual pain disorders, such as vulvodynia and vestibulodynia. ${ }^{[6]}$ Women with vaginismus need both physical and emotional support to overcome this condition. It is possible to effectively treat women struggling with vaginismus using various approaches. Stratification of the vaginismus helps to determine the most suitable course of treatment. ${ }^{[23]}$

A multidisciplinary approach is the most appropriate and effective means to evaluate and address the diverse dimensions of vaginismus. ${ }^{[10]}$ Our clinic uses this approach to develop and administer individualized treatment. Cognitive therapy sessions include accurate information about the hymen, genital anatomy and physiology, first penetration, and sexuality, and behavioral therapy techniques include pelvic rehabilitation and Kegel exercises, mirror exercises, sensate exercises, and finger and dilator exercises. All of the exercises are explained in a clinical setting with a therapist. Our team includes gynecologists, psychologists, family counselors, physiotherapists, and nurses who are trained in this field.

There appears to be no previously published research related to the treatment of vaginismus during pregnancy. Most physicians avoid starting vaginismus treatment for a pregnant patient because they don't want to take the risk of pregnancy complications. Our findings showed that there was no effect on pregnancy outcomes or significant difference in treatment results between the pregnant vaginismus patients, who may have become pregnant without complete penetration, and the non-pregnant vaginismus group. We contend that vaginismus treatment can be conducted safely during pregnancy. There may, in fact, be benefits to not delaying treatment. Pregnant patients will frequently postpone treatment for an average of $\mathrm{I}-\mathrm{I} .5$ years during pregnancy and the postpartum period. This can create an additional burden for many couples and may lead to marital problems. It has been suggested that perception of birth as a fearful experience may exacerbate sexual dysfunction. [8] Without treatment, a preference for a cesarean delivery is more likely. Studies have demonstrated that vaginismus is an independent risk factor for cesarean section. ${ }^{[8,24]}$ It has been reported that women with vaginismus were more likely to request birth induction ( $37 \%$ vs. $27 \%$ ), have forceps extraction ( $9 \%$ vs. $3 \%$ ), and cesarean delivery (39\% vs. $15 \%)$ compared with women who do not have vaginismus.
[24] In our study, 5 of 17 pregnant vaginismus patients were able to have a vaginal delivery, thereby reducing the surgical risks associated with a cesarean section. Elective cesarean delivery was performed in 7 of 12 patients who delivered by cesarean section. Medical indications, such as fetal macrosomia, intrauterine growth restriction, preterm labor, and primigravida breech presentation, were present in the other 5 cesarean deliveries. After treatment for vaginismus, many patients can overcome vaginismus and comfortably allow penetration. This will facilitate examinations and the remainder of pregnancy, as well as contribute to quality of life.

In addition to the important psychological contributions of other family relationships, it has been noted that some patients with vaginismus have a family history of vaginismus. It has been suggested that female relatives, such as grandmothers, mothers, twins, and sisters may contribute to an auditory fear conditioning effect in the anticipation of pain and fear of penetration. ${ }^{[23]}$ In this study, there was a family history of vaginismus in both groups. We think that it is coincidental that the history of vaginismus was higher in the families of pregnant vaginismus patients. Our results indicated that the pregnant vaginismus patients responded to the treatment faster; non-pregnant vaginismus patients required a significantly greater number of days of treatment and more sessions than the pregnant vaginismus patients to achieve a satisfactory response. After treatment, the pregnant patients reported a higher rate of partial sexual intercourse than the women in the other group. Since these patients had become pregnant, it is not entirely surprising that their vaginismus may have been somewhat less severe and treatment was successful with fewer sessions.

In conclusion, we found that patients with a normal-risk, second trimester pregnancy who pursued treatment for vaginismus could be treated safely and successfully, and that in some respects, results may be seen sooner in this group of vaginismus patients. To our knowledge, this is the first study to examine vaginismus treatment during pregnancy. Successful treatment could confer advantages such as decreased preference for caesarean section, reduced anxiety related to gynecological exams and delivery, and less postponement of treatment.

\section{Acknowledgements}

We would like to acknowledge Dr. S.S.Ç. for assistance with data collection and MakaleTercume for their scientific proofreading and editing services.

\section{Funding}

This research did not receive any specific grant from funding agencies in the public, commercial, or not-for-profit sectors. All of the authors declare that they have no conflict of interest.

\section{Ethics Committee Approval}

The study was approved by the Kartal Dr. Lütfi Kırdar City Hospital Clinical Research Ethics Committee on March 30, 2020 (no: 2020/5 |4//86/2). 


\section{Informed Consent}

\section{Retrospective study.}

Peer-review

Internally peer-reviewed.

Authorship Contributions

Concept: S.E.; Design: S.E.; Supervision: S.E.; Fundings: E.E.A.; Materials: S.E.; Data: E.E.A.; Analysis: E.E.A.; Literature search: E.E.A.; Writing: S.E.; Critical revision: S.E.

Conflict of Interest

None declared.

\section{REFERENCES}

1. Anğın AD, Gün İ, Sakin Ö, Çıkman MS, Eserdağ S, Anğın P. Effects of predisposing factors on the success and treatment period in vaginismus. JBRA Assist Reprod 2020;24:180-8.

2. Melnik T, Hawton $\mathrm{K}, \mathrm{McGuire} \mathrm{H}$. Interventions for vaginismus. Cochrane Database Syst Rev 2012;12:CD001760.

3. American Psychiatric Association. Diagnostic and statistical manual of mental disorders DSM-5.5th ed. Washington, DC: American Psychiatric Association; 2013.

4. Binik YM. The DSM diagnostic criteria for vaginismus. Arch Sex Behav 2010;39:278-91.

5. Pacik PT, Babb CR, Polio A, Nelson CE, Goekeler CE, Holmes LN. Case series: redefining severe grade 5 vaginismus. Sex Med 2019;7:489-97.

6. Pacik PT, Geletta S. Vaginismus treatment: clinical trials follow up 241 patients. Sex Med 2017;5:114-23.

7. Lahaie MA, Amsel R, Khalifé S, Boyer S, Faaborg-Andersen M, Binik YM. Can fear, pain, and muscle tension discriminate vaginismus from dyspareunia/provoked vestibulodynia? Implications for the new DSM-5 diagnosis of genito-pelvic pain/penetration disorder. Arch Sex Behav 2015;44:1537-50.

8. Möller L, Josefsson A, Bladh M, Lilliecreutz C, Sydsjö G. Reproduction and mode of delivery in women with vaginismus or localised provoked vestibulodynia: a Swedish register-based study. BJOG 2015;122:329-34.

9. Achour R, Koch M, Zgueb Y, Ouali U, Ben Hmid R. Vaginismus and pregnancy: epidemiological profile and management difficulties. Psychol Res Behav Manag 2019;12:137-43.

10. Lahaie MA, Boyer SC, Amsel R, Khalifé S, Binik YM. Vaginismus: a review of the literature on the classification/diagnosis, etiology and treatment. Womens Health (Lond) 2010;6:705-19.

11. Yaraghi M, Ghazizadeh S, Mohammadi F, Ashtiani EM, Bakhtiyari $\mathrm{M}$, Mareshi SM, et al. Comparing the effectiveness of functional electrical stimulation via sexual cognitive/behavioral therapy of pelvic floor muscles versus local injection of botulinum toxin on the sexual functioning of patients with primary vaginismus: a randomized clinical trial. Int Urogynecol J 2019;30:1821-8.

12. Crowley T, Goldmeier D, Hiller J. Diagnosing and managing vaginismus. BMJ 2009;338:b2284.

13. Crowley T, Richardson D, Goldmeier D; Bashh Special Interest Group for Sexual Dysfunction. Recommendations for the management of vaginismus: BASHH Special Interest Group for sexual dysfunction. Int J STD AIDS 2006;17:14-8

14. Jindal UN, Jindal S. Use by gynecologists of a modified sensate focus technique to treat vaginismus causing infertility. Fertil Steril 2010;94:2393-5.

15. Nguyen RH, Stewart EG, Harlow BL. A population-based study of pregnancy and delivery characteristics among women with vulvodynia. Pain Ther 2012;1:2.

16. Lamont JA. Vaginismus. Am J Obstet Gynecol 1978;131:633-6.

17. Mehta C, Patel N. A hybrid algorithm for Fisher's exact test in unordered RXC contingency tables. Commun Stat Theory Methods 1986;15:387-403

18. Simonelli C, Tripodi F, Cosmi V, Rossi R, Fabrizi A, Silvaggi C, et al. What do men and women ask a helpline on sexual concerns? Results of an Italian telephone counselling service. Int J Clin Pract 2010;64:360-70.

19. Bravo C, Melendez J, Ramirez S, Lopez M. Feminine and masculine sexual dysfunctions: gender comparison in a Mexico City sample. Salud Mental 2005;28:74-80.

20. Amidu N, Owiredu WK, Woode E, Addai-Mensah O, Quaye L, Alhassan $\mathrm{A}$, et al. Incidence of sexual dysfunction: a prospective survey in Ghanaian females. Reprod Biol Endocrinol 2010;8:106.

21. Dogan S. Vaginismus and accompanying sexual dysfunctions in a Turkish clinical sample. J Sex Med 2009;6:184-92.

22. Pacik PT. Vaginismus: review of current concepts and treatment using botox injections, bupivacaine injections, and progressive dilation with the patient under anesthesia. Aesthetic Plast Surg 2011;35:1160-4.

23. Pacik PT. Understanding and treating vaginismus: a multimodal approach. Int Urogynecol J 2014;25:1613-20.

24. Goldsmith T, Levy A, Sheiner E, Goldsmith T, Levy A, Sheiner E. Vaginismus as an independent risk factor for cesarean delivery. J Matern Fetal Neonatal Med 2009;22:863-6.

\section{Gebelikte Vajinismus Tedavisinin Özelliklerinin ve Klinik Sonuçlarının Değerlendirilmesi}

Amaç: Vajinismus, kadınların yaşam kalitesinde önemli rahatsızlığa ve bozulmaya neden olabilecek en yaygın kadın psikoseksüel işlev bozukluklarından biridir. Çalışmanın amacı gebelikte vajinismusun özelliklerini değerlendirmekti.

Gereç ve Yöntem: Bu çalışmaya riskliği gebeliği olmayan ancak vajinismusu olan 17 gebe ve gebe olamayan (kontrol) 34 vajinismus hastası dahil edildi. Her iki gruptaki tüm hastalar bilişsel cinsel terapiler ve davranışsal tedavilerle tedavi edildi. Vajinismus tedavisi nedeniyle gebelik komplikasyonu görülmedi.

Bulgular: Gebe olan vajinismus grubunda seans sayısı ve seanslara toplam katılım gün sayısı kontrol grubundan anlamlı olarak daha azdı. Vajinismusu olan gebelerin on ikisinde sezaryen, beşinde vajinal doğum mevcuttu. Sezaryen doğumlardan yedisinin endikasyonu elektifti ve beşinin farklı tıbbi endikasyonları vardı. Tedaviden sonra 16 çift (\%94.I), tam penetrasyonlu cinsel ilişkiye çok rahat bir şekilde kavuştu, ancak bir çift tam penetrasyona sahip olduklarını ancak ağrılı olduğunu belirtti.

Sonuç: Yaptığımız bu çalışma gebelik sırasında vajinismus tedavisi ile ilgili ilk çalışmadır. Cinsel ilişki olmadan zaman zaman gebe kalan vajinismus hastalarının hamilelik sırasında güvenli bir şekilde cinsel terapi alabileceğini ve sonuçların gebe olmayan vajinismus hastalarından daha iyi olduğunu gözlemledik.

Anahtar Sözcükler: Başarı; doğum; gebelik; tedavi; vajinismus. 